THE NATION I N THE VILLAGE 



\section{THE NATION IN THE VILLAGE}

The Genesis of Peasant National Identity in Austrian Poland, I848-I9I4

\section{KEELY STAUTER-HALSTED}

CORNELL UNIVERSITY PRESS

Ithaca and London 


\section{Copyright (C) 2001 by Cornell University}

All rights reserved. Except for brief quotations in a review, this book, or parts thereof, must not be reproduced in any form without permission in writing from the publisher. For information, address Cornell University Press, Sage House, 512 East State Street, Ithaca, New York 14850.

First published 2001 by Cornell University Press

First printing, Cornell paperbacks, 2004

Printed in the United States of America

\section{Library of Congress Cataloging-in-Publication Data}

Stauter-Halsted, Keely, 1960-

The nation in the village : the genesis of peasant national identity in Austrian Poland, 1848-1914 / Keely Stauter-Halsted.

p. $\mathrm{cm}$.

Includes bibliographical references and index.

ISBN 0-8014-3844-6 (cloth: alk. paper)

ISBN 0-8014-8996-2 (pbk.: alk. paper)

1. Peasantry-Galicia (Poland and Ukraine)-Political activity. 2. Peasantry-Galicia (Poland and Ukraine)-History-19th century. 3. Peasantry-Galicia (Poland and Ukraine)-History-20th century. I. Title.

HD1536.P7S7 2001

$943.8^{\prime} 6032-\mathrm{dc} 21$

Cornell University Press strives to use environmentally responsible suppliers and materials to the fullest extent possible in the publishing of its books. Such materials include vegetablebased, low-VOC inks and acid-free papers that are recycled, totally chlorine-free, or partly composed of nonwood fibers. Books that bear the logo of the FSC (Forest Stewardship Council) use paper taken from forests that have been inspected and certified as meeting the highest standards for environmental and social responsibility. For further information, visit our website at www.cornellpress.cornell.edu.

$\begin{array}{lllllllllll}\text { Cloth printing } & 10 & 9 & 8 & 7 & 6 & 5 & 4 & 3 & 2 & 1\end{array}$

$\begin{array}{lllllllllll}\text { Paperback printing } & 10 & 9 & 8 & 7 & 6 & 5 & 4 & 3 & 2 & 1\end{array}$ 